\title{
Clue Cell Count
}

National Cancer Institute

\section{Source}

National Cancer Institute. Clue Cell Count. NCI Thesaurus. Code C102261.

The determination of the amount of clue cells present in a sample. 